\title{
Indicator count methods tested out on Møn, Denmark
}

\author{
Per Smed
}

Abstract:

Indicator rock counts were carried out in four till units on the island Møn, Denmark. The results were depicted as "circle maps". These showed that the contents of the four units were distinctly different, an observation that could not have been shown with comparable clarity with other methods, such as the calculation of the theoretical centre of dispersal (TGZ). Therefore the Møn counts have been used as a starting point for a method review, including information that has been neglected so far. The indicator counts reveal that the interpretation of the Klintholm till as of "Baltic provenance" should be revised, and that ABER's (1979) interpretation of the till units at Hvideklint based on fine gravel has to be refuted.

[Leitgeschiebezählungs-Methoden, durch Untersuchungen auf der Insel Møn, Dänemark, geprüft]

Kurzfassung:

Leitgeschiebezählungen wurden in vier Tills in Kliffprofilen auf der Insel Møn, Dänemark durchgeführt. Die Resultate sind als „Kreis-Karten“ abgebildet. Die in dieser Arbeit vorgelegten Till-Einheiten sind distinkt verschieden. Diese Unterschiede konnten bislang mit anderen Methoden nicht entsprechend klar gezeigt werden, so z. B. durch die Berechnung des theoretischen Geschiebezentrums (TGZ). Deshalb wurden die Møn-Zählungen als Ausgangspunkt für eine Methodenkritik verwendet, mit Hinweisen auf bisher unbeachtet gebliebene Information. Von lokalem Interesse ist, dass die „baltische“ Provenienz des Klintholm Tills revidiert werden sollte, und dass die von ABER (1979) vorgelegte und auf Feinkies basierte Interpretation von Till-Einheiten im HvideklintProfil abgelehnt werden muss.

Keywords:

Indicator counts, circle maps, Møn, till provenance, depiction methods

Address of author: $\quad$ Per Smed, Stiholmsvej 1, DK-3460 Birkerød. E-Mail: a_smed@post.tele.dk

\section{Introduction}

A major problem for indicator counting has always been the randomness with which recognizable rock types have become known over time. Furthermore, every geologist uses his/her own type selection, so that the results cannot be not fully compared. To assure that valuable information can be drawn from a count procedure, one should take into account that (1) approximately the same percent of the total clast content should be counted in every investigated till, and that (2) the source areas of the rock types used should be as evenly distributed as possible.

The latter demand is difficult to fulfill. Below, the historically most important methods (Milthers 1909, 1942, HeSEMANN 1936, 1975, and LüTTIG 1958) shall be reviewed with reference to this and to other problems. In order to illustrate the inferences, hitherto unpublished material shall be presented, including results from the investigation of four tills occurring in cliff sections on the south coast of the island Møn, Denmark; indicator counts in three of these are published here (fig. 5, 6, 7).

All mentioned samples were taken directly from the tills (in situ). Indicator counts of glaciofluvial gravel are regarded as less reliable, since meltwater can erode deep into the substratum (more than $100 \mathrm{~m}$ has been mentioned). Stones from fields were not used, since their stratigraphic position is uncertain (the youngest till can be missing in the area, and some stones could come from dug trenches, building sites, etc.)
The author's indicator type selection is based on HEsEmAnN (1936, 1975) and LüTTIG (1958), supplemented by a number of types proposed by Zandstra (1988, 1999), WenNBERG (1949), VINX $(1996,1998)$ and the present author. Most of the used types are depicted in SMED $(1995,2002)$. The significance of the selection is discussed in section 3.1.

The circle-map method was first presented by SMED $(1989,1993)$. Its essential procedure is a drawing of maplets of southern Scandinavia, one map for each count (fig. 5, $6,7)$. In these maplets, a circle represents one rock type or a cluster of neighbouring variants; the circle center is situated in the middle of the outcrop area, and the circle area is proportional to the number of specimens found. This method has several advantages: (1) every indicator rock type used and every identified clast is shown; (2) comparisons between map pictures are easier than comparison between formulae or indicator lists; (3) in most cases, the circles turn out to constitute a band between the Scandinavian source areas and the sampling site, indicating an ice movement path; (4) reworked stones lie often outside the band or blur the band and can thus be identified.

Regardless of the method used, an indicator count can only be a spot test. A usable procedure is to look after clasts with identifiable source areas until a significant number (usually 50) has been reached. If 50 specimens cannot be found at the face of the section, a spade must be used. No rules can be set down about the till volume that needs to be dug out; the objective is the statistical significance (50 samples). 
A computer program constructed by GeISLER-Wierwille (pers. comm.), Hamburg and Bonn, Germany has been used to draw the circle maps.

\section{Samples from the island Møn, Denmark}

Figures 3a, 3b, and 4 illustrate the stratigraphy and glacial tectonics in the cliffs on the south coast of Møn. The units involved are: (C) Cretaceous chalk, (a) Ristingeklint till (the unit is missing in fig. 4), (b) Klintholm till with shear mix, (c) Mid Jutland till, (d) Young Baltic till. All till units are Weichselian. They shall be described here in brief:

\section{The Ristingeklint till}

This till is exposed at the cliff localities Hjelm Nakke and Hvideklint. In Houmark-NiELSEN (1994) the till is referred to as Unit 4. Its occurrence has been known since older descriptions of Møns klint (Hintze 1937). The till has a distinctly Baltic provenance, with few Swedish clasts; the content of Palaeozoic limestone pebbles is very high. In many places, e. g. at Hjelm Nakke, the Ristingeklint till rests directly on chalk, but in spite of this, the percentage of flint clasts in the till is much lower than the percentage of crystallines, whereas in the overlying till units the opposite is the case.

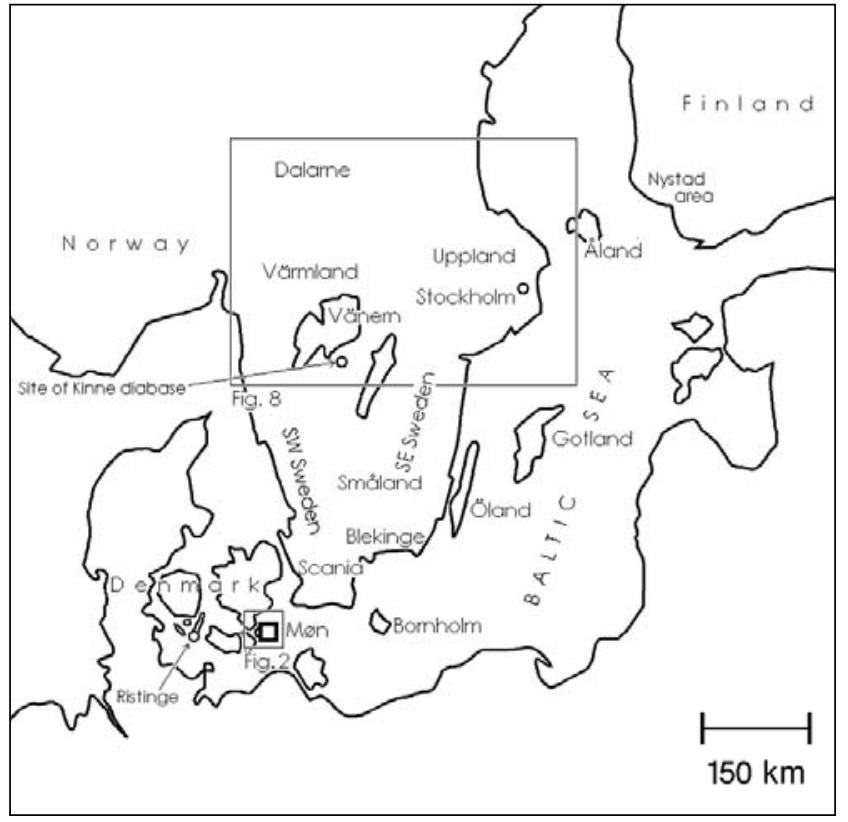

Fig. 1: Overview of geographical names used in the article. Outlines of fig. 2 and 8 are shown.

Abb. 1: Ubersicht der im Artikel verwendeten geographischen Namen. Die Lage der Abb. 2 und 8 sind als Umrisse angegeben.

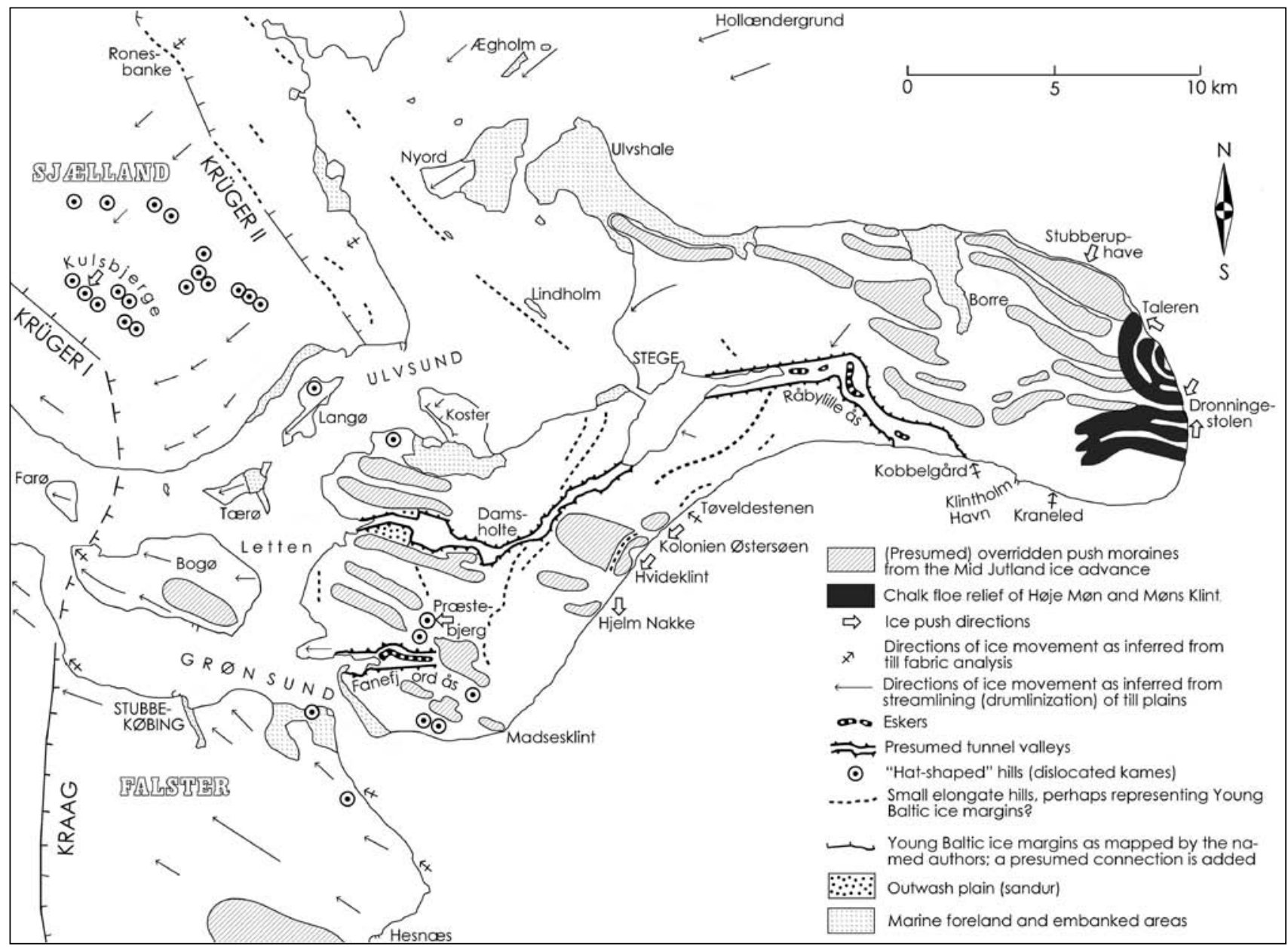

Fig. 2: Glacial landscape and locality names on the island Møn, Denmark. The map is based on information from KRÜGER (1969), KRAAG (1978), HOUMARKNIELSEN (1994), from the author's own observations, and from KRÜGER (pers. comm.), and HOUMARK-NIELSEN (pers. comm.).

Abb. 2: Glaziale Landschaft und untersuchte Lokalitäten auf der Insel Møn. Die Karte basiert auf Informationen aus KRÜGER (1969), KRAAG (1978), HOUMARK-NIELSEN (1994), Beobachtungen des Autors und persönlichen Mitteilungen von f. KRÜGER Und M. HOUMARK-NIELSEN. 


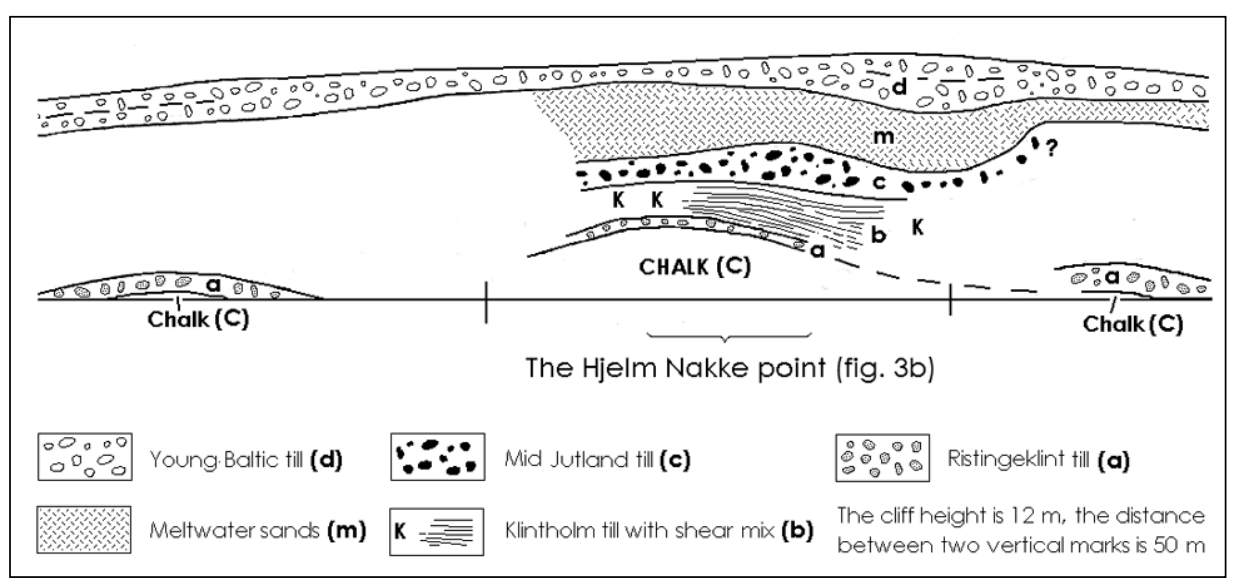

Fig. 3a: Overview of the Hjelm Nakke cliff profile. The photograph fig. $3 b$ covers the section above the brace.

Abb. 3a: Ubersicht des Profils Hjelm Nakke. Die Abb. 3b gibt den Abschnitt oberhalb der Klammer wieder.

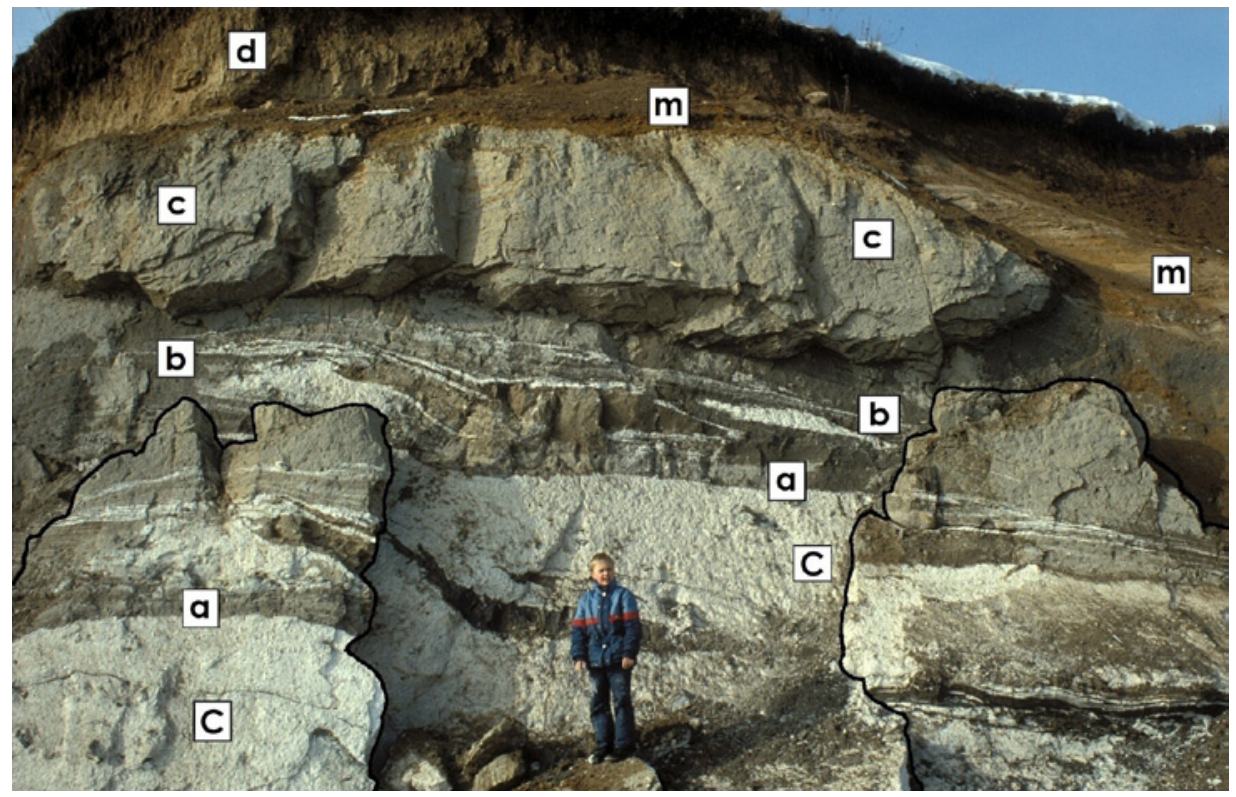

Fig. 3b: Hjelm Nakke cliff. The exposed units are marked with the same letters as in fig. 3A. Black lines surround blocks that have slided downwards (Photograph by MiCHAEL HOUMARK-NIELSEN).

Abb. 3b: Das Hjelm Nakke Kliff. Die dargestellten lithologischen Einheiten entsprechen Abb. 3a. Die schwarzen Linien markieren die Umrisse von hangabwärts verrutschten Blöcken (Foto MICHAEL HOUMARK-NIELSEN).

(At Hjelm Nakke 33 flints and 124 crystallines were counted on a $1 \mathrm{~m}^{2}$ surface in the Ristingeklint till; in the overlying Klintholm till, the numbers were 62 flints and 18 crystallines). Eight Åland rocks were found In Ristingeklint till in only a quarter of an hour; no rocks from Åland were found in Klintholm till at the same site, not even after two days of sampling. The unweathered Ristingeklint till is grey, a little bluish when wet, and reddish brown (sienna) in a weathered state. Locally it displays red streaks and stains. As it includes rafts of Eemian material, its stratigraphic position as Weichselian is beyond doubt (KRÜGER \& KJÆR 1999). The till represents an Early/Middle Weichselian ice advance; its age is estimated at $50.000 \mathrm{ybp}$ by HouMARK-NIELSEN and KJÆR (2003). It has also been found at Ristinge on Langeland (SJøRRING 1983) and on Djursland in east Jutland (PEDERSEN \& Petersen 1997).

\section{The Klintholm till}

This till is exposed at all investigated localities. In HoumARKNielsen (1994) it is referred to as Unit 6. It underlies lacustrine layers deposited during the Denekamp interstadial. The author's five counts from the Klintholm till produced strikingly similar results (fig. 5, 6, 7): they represent a path of ice transport from the Scandinavian mountains via Dalarne, through eastern Sweden, along the east coast of Småland and via Blekinge towards Møn. Palaeozoic limestones from areas near the Swedish coast are abundant; rock types from the eastern Baltic were not found. The transport path has a clear western boundary: no Kinne diabases, Värmland granites, garnet amphibolites, or Scanian basalts occurred. Instead, Kalmarsund sandstones, Öland limestones, and white-spotted flints were found. The spotted flints derive from Campanian littoral limestone deposits in NE Scania and from the present sea floor S of Blekinge.

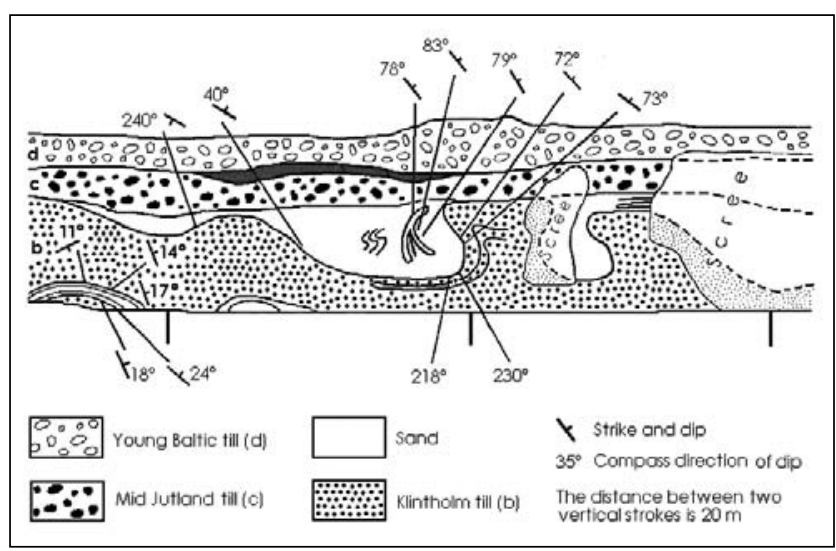

Fig. 4: Part of the "Kolonien Østersøen" cliff section, by courtesy of M. FAURBYE. Abb. 4: Abschnitte der „Kolonien Østersøen “Kliff Sektion (mit Genehmigung M. FAURBYE). 


\section{The Mid-Jutland till}

The unit has traditionally been called "NE-ice till"; it was designated as the Mid Jutland till by HoumARK-NIelsEN (1987), i. e. interpreted as deposited when the ice advanced to the Mid Jutland marginal line 23-21 kyr bp. The till can be observed at Hjelm Nakke as well as in the "Kolonien Østersøen" cliff (FAuRBYe 1999), overlying Denekamp interstadial strata. It is hard and massive (cf. the photograph fig. $3 b)$, probably reflecting the load of a thick ice cover. The circle map (fig. 5) combines the results of SMED and FAURBYE.

The photograph fig. 3b shows a protruding mass (c), interpreted as the Mid Jutland till by STOCкMARR (1996), and by HOUMARK-NielSEN (pers. comm.). A sharply defined interface separates the protruding mass from an underlying sheared sediment mixture (b), consisting mostly of $\mathrm{cm}$ - or $\mathrm{dm}$-thick smears of alternately white chalk and black clay. Thin till layers are also present, but they are less coherent than the protruding mass above, and have another colour. Steep N-dipping joints in the protruding till mass (visible in the photograph) do not continue into the shear mix; thus the interface most probably represents the base of the Mid Jutland unit. The shear mix is overthrusted from the $\mathrm{N}$ along fault planes with a low inclination $\left(15-30^{\circ}\right)$.The Mid Jutland ice sheet moved from the $\mathrm{N}$ locally; thus the Mid Jutland ice sheet was most likely responsible for the shearing and thrusting.

In cliff profiles between Hjelm and Tøvelde, the Klintholm and Ristingeklint tills as well as the underlying chalk are disturbed by pressure coming from the NW to E, on average about NE. Fig. 3 shows gentle folds with long amplitudes,
$30 \mathrm{~m}$ or more, over which the Mid Jutland till forms an undisturbed cover. The folding is more intense in fig. 4, but the Mid Jutland till tops it in the same way. Almost undisturbed meltwater strata and a Young Baltic till cover the sequence.

\section{The Young Baltic till}

The Young Baltic till is found at all investigated sites. In HoumARK-Nielsen (1994) it is referred to as Unit 8. It is light-grey in a fresh state, but brown when weathered. It forms a 1-3 $\mathrm{m}$ thick blanket at the land surface, overlying normally undisturbed meltwater deposits; $\mathrm{dm}$-sized folds are observed locally, and $10-30 \mathrm{~cm}$ thick slabs of chalk are found, mostly at the base of the till. Red sandstones are common, often in long bands of tiny pebbles. In some places, the crushing has gone so far that the till matrix displays red stains or streaks (cf. KRÜGER \& KJÆR 1999). Åland rocks are common and Småland granites rare in the Young Baltic layers, whereas the opposite is the case in the Klintholm till. White-spotted flints are less common than in the Klintholm unit; Öland limestones occur in both the Klintholm and the Young Baltic tills.

\section{Discussion of indicator count methods}

\subsection{A control count at Ristinge and comments on the Milthers method}

In 1989, an attempt was made to access the significance of the author's type selection by means of a beach stone count

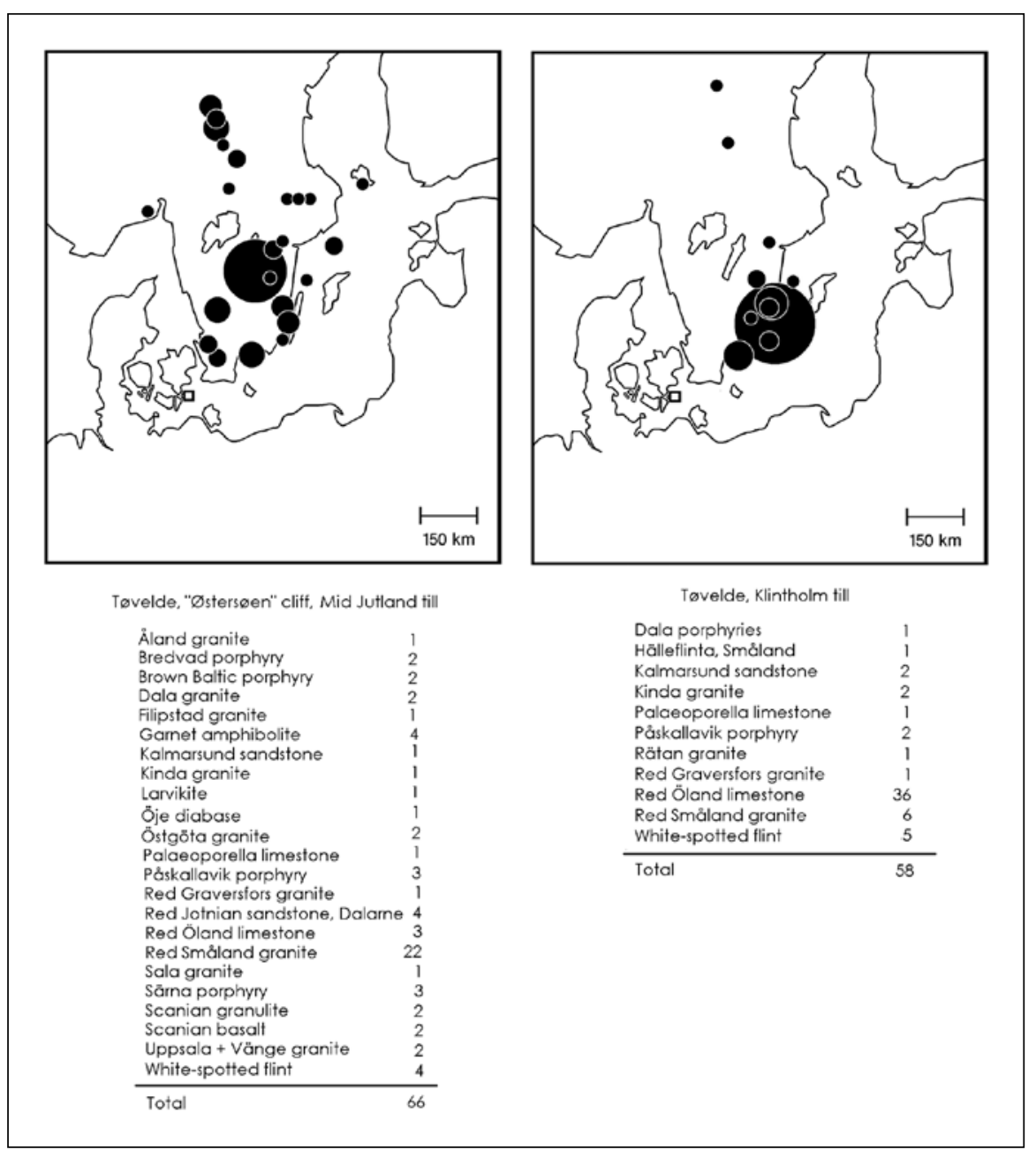

Fig. 5: Two indicator counts from the "Kolonien Østersøen” cliff section near Tøvelde. The samples of Mid futland till were taken above the large fold in fig. 4; the Klintholm till sample was taken immediately to the right (NE) of fig. 4. In the figs. 5, 6, and 7 the square represents the investigated locality. Abb. 5: Zwei Geschiebezählungen aus der „Kolonien Østersøen“ Kliff Sektion bei Tøvelde. Die Proben aus dem Mid futland till wurden oberhalb der großen Falte (s. Abb. 4) entnommen, die Klintholm till Probe wurde im direkten Anschluss (NE, s. Abb. 4) entnommen. Die Lage des Untersuchungspunktes ist in den Abb. 5-7 durch jeweils ein Quadrat gekennzeichnet. 


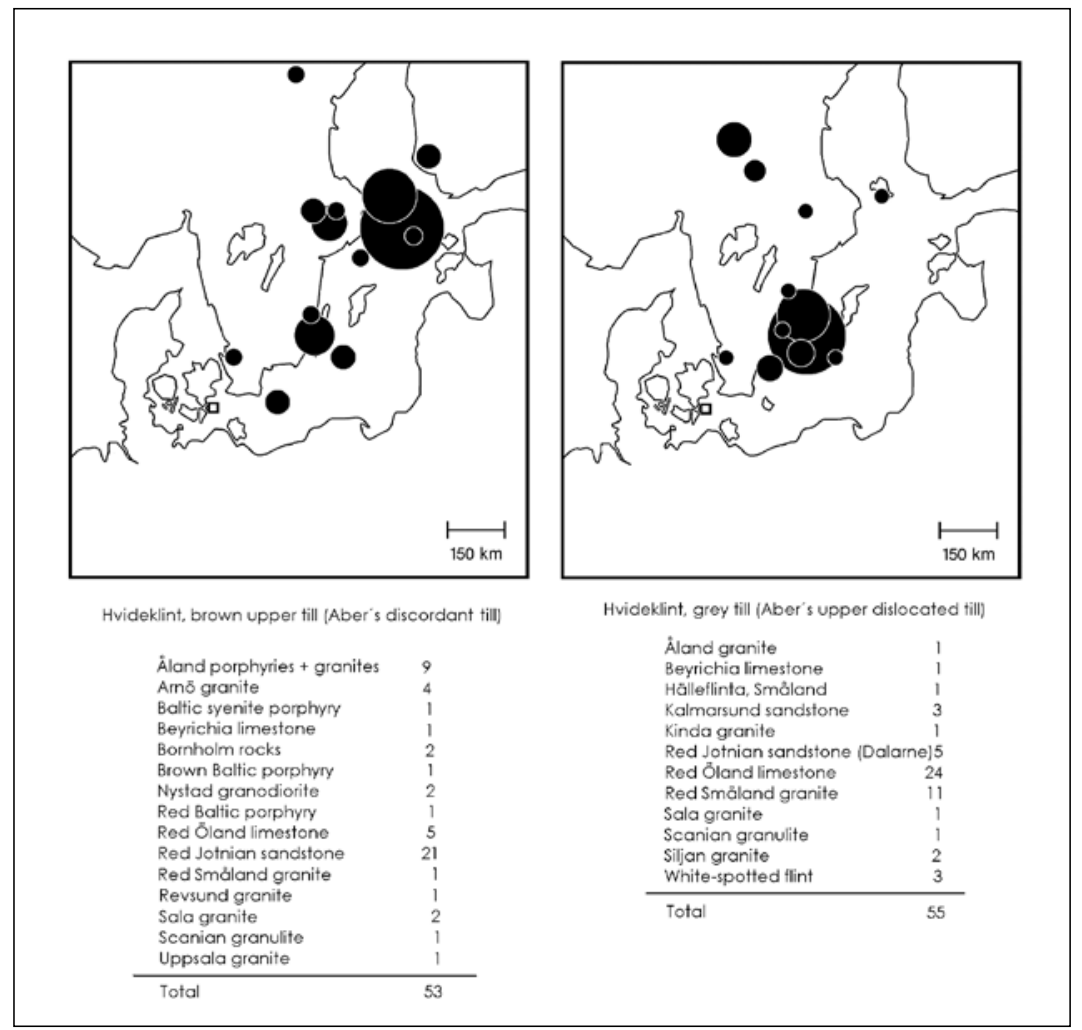

Fig. 6: Two indicator counts from the Hvideklint cliff. Both samples were taken 650-40 $\mathrm{m}$ NE of the end of the road Ørebækvej, cf. fig. 12.

Abb. 6: Zwei Geschiebezählungen aus dem Hvideklint Kliff. Beide Proben wurden 650-640 m NE des Endes des Ørebækvej entnommen (s. Abb. 12).

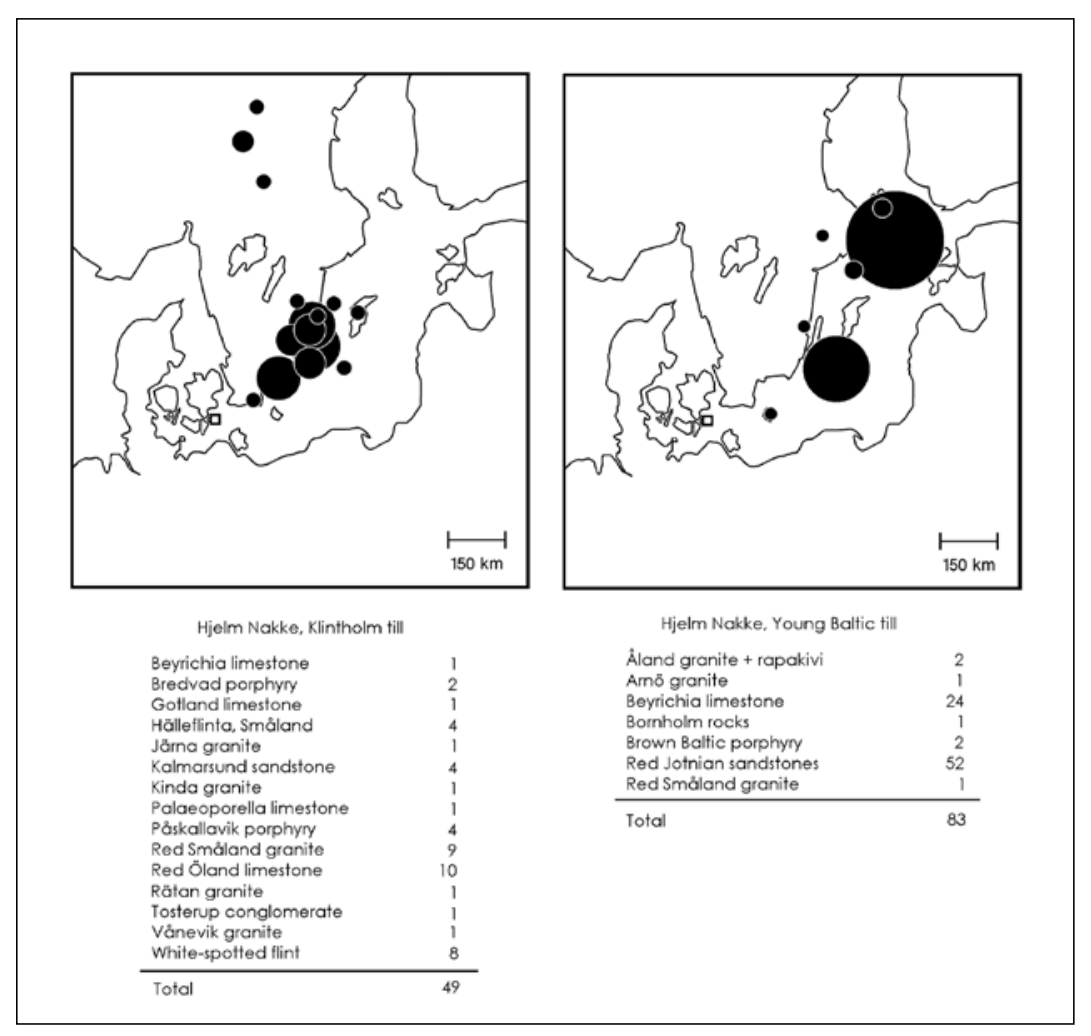

Fig. 7: Two indicator counts from the Hjelm Nakke cliff. The Klintholm till was sampled immediately to the right of the photograph fig, 3b, $240 \mathrm{~m} N E$ of the end of the road Hjelmnakkevej; the Young Baltic till was sampled 50-100 $\mathrm{m} \mathrm{NE}$ of that road end.

Abb. 7: Zwei Geschiebezählungen aus dem Hjelm Nakke Kliff. Der Klintholm till wurde direkt am rechten Rand der auf Abb. $3 b$ dargestellten Sektion beprobt (240 m NE des Straßenendes des Hjelmnakkevej. Der Young Baltic till wurde 50-100 m NE des Straßen-endes beprobt. at Ristinge cliff (Langeland, Denmark). The till thicknesses and provenances in this cliff profile are well known, cf. SJøRRING (1983). Furthermore, the cliff is situated on a peninsula pointing towards the dominating wind direction, a position preventing coast-parallel wave transportation of stones from the $\mathrm{W}$. The beach $\mathrm{E}$ of the cliff is sandy, indicating that a transport from that direction is negligible. Thus the stones on the beach must derive from erosion of the local cliff. Therefore, the ratio between Swedish and Baltic stones on the beach should roughly correspond to the ratio between the thicknesses of Swedish and Baltic tills in the cliff.

An about $5 \mathrm{~m}$ thick Mid Jutland till series with Swedish provenance dominates the profile. A Young Baltic till lies above it and a Ristingeklint till with Baltic provenance lies below it; the two have a combined thickness of about 1,5 m. 192 indicators were counted on the beach. Of these, 31 were (strictly speaking) of Baltic provenance, 13 were from the Stockholm region (Uppland), 147 from the rest of Sweden (from Dalarne on to Scania) and 1 from Norway. Uppland stones can be reckoned as Baltic indicators in practice, cf. fig. 8. Therefore, it can be assumed that 44 indicators were transported to the locality via the Baltic depression, as compared to 147 transported via central and southern Sweden. The ratio between the thicknesses of the Baltic and the Swedish tills is 1,5:5 = 3:10. The ratio between 44 and 147 is 2,99:10. The conclusion seems to be that a rather well balanced number of counted samples derives from these two main source areas.

MiLthers's beach stone count method (1909, 1942) was used at Ristinge by its inventor; his count showed a ratio of $12 \mathrm{Bal}-$ tic: 10 Swedish indicators. Milthers often disregarded the Kinne diabases; if that is done here, the result is 71 Baltic and 26 Swedish indicators, a proportion of 27:10 (the figures are based on K. Milthers 1942). These ratios do not approach the ratio between the till thicknesses, not even with a reasonable margin of error. It must be concluded that Swedish rock types were catastrophically under-represented when MiLthers's rock type selection was applied.

\subsection{The Hesemann method}

In Germany, the most used method has been that of HESEMANN (1931, 1936, 1975). His counts include more rock types than that of MiLthers used. However, as LüT- 
TIG (1958) objects, the presentation method blurs the results: Hesemann subdivided Norden into four areas (fig. 9). For each count, the determined indicator clasts were sorted out into four groups, corresponding to the four areas. Thus, individual rock types were not depicted, and therefore, the accuracy of the analyses was limited. Furthermore, the boundary between the HesEmANN areas "II" and "III" crosses the striae and the transport direction of Dalarne rocks towards the S on to Småland-Scania, cf. fig. 8. Stones from Uppland (the Stockholm area) were lumped together with Dalarne rocks, but as shown by the striae, the ice carried the Uppland rocks out into the Baltic sea. This corresponds with observations made in Sweden (few or no stones from Dalarne can be found near Stockholm) and with results from Danish counts. The Dalarne and Uppland rocks do not occur together in the way Hesemann presupposed. Furthermore, all south Swedish clasts were piled in HesEmanN's group III (cf. fig. 8 and 9). This would have made the difference between the Klintholm till and the Mid Jutland till (fig. 5) invisible; it would be concealed that Klintholm till contains many stones from SE Sweden, but none from SW Sweden.

Unfortunately, the mentioned traits influence HESEMANN's "formulae" in a disadvantageous way. Since the digit in blank IV (representing Norway) is normally 0 in German counts, the only information of real value in the formulae seems to be the relation between the number of clasts from the eastern/northern Baltic (blank I) and the entire rest (blanks II + III). The full indicator lists are, however, published and are still of value today.

\subsection{The Lüttig method}

LÜTTIG (1958) listed each rock type separately, and calculated an average geographical position for all clasts in a count (the so-called TGZ), thus avoiding any subdivision of Scandinavia.

Four problems with the TGZ method will be discussed here: (A) that some sandstone types are counted, but most

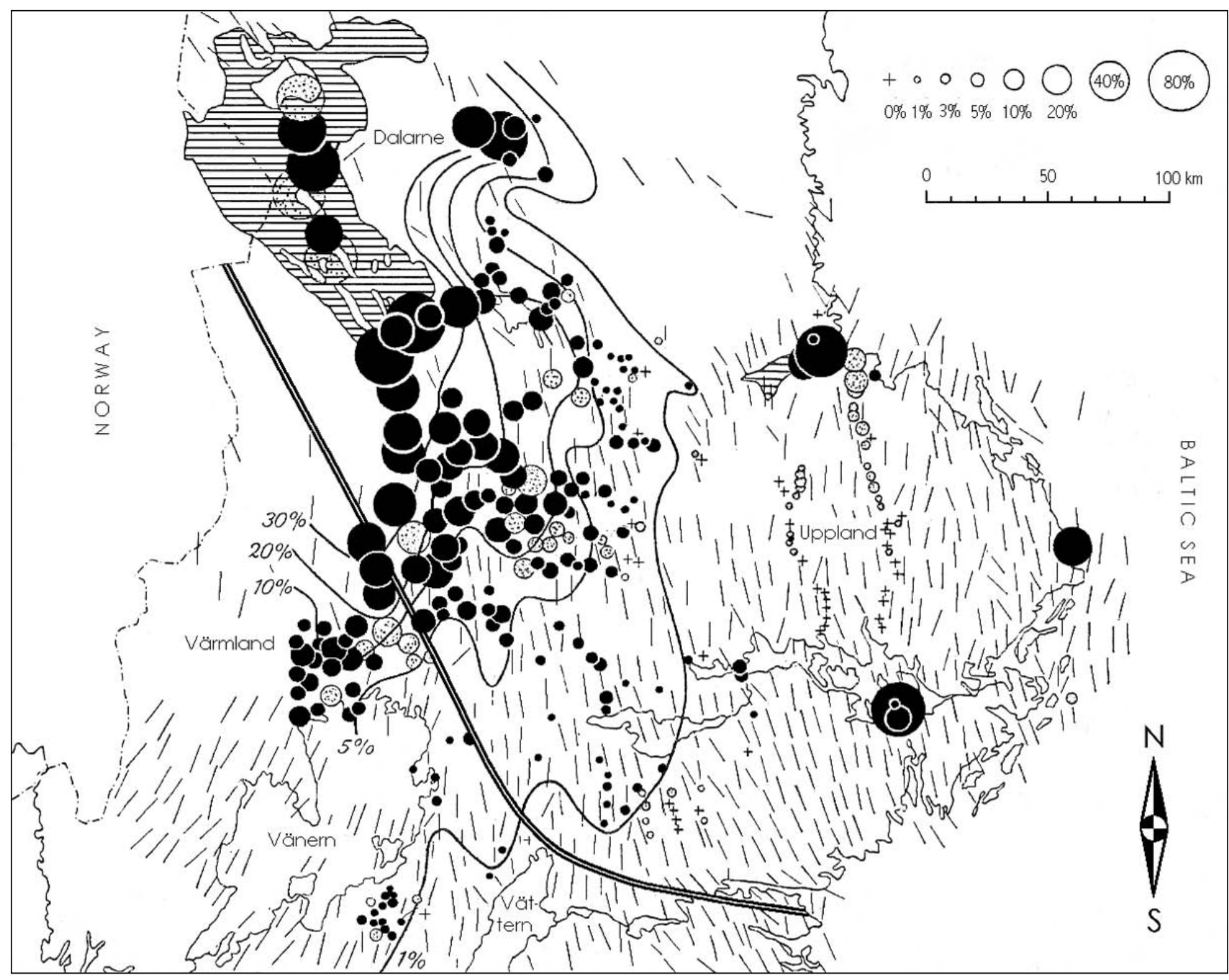

Fig. 8: Directions of striae, and the spreading of Dala sandstones from the source area (hatched). The circles show sandstones as a percentage of the total number of clasts at each location. The dotted circles represent meltwater deposits. The occurrences at Gävle (N of Uppland) and Stockholm (S of Uppland), as well as in the stripe between these points, derive from small local outcrop areas (G. LUNDQVIST 1935, 1951). The double line (added by the present author) is the boundary between HESEMANN's indicator areas II (NE of the line) and III (SW of the line), cf. fg. 9.

Fig. 8: Gletscherschrammen sowie Verbreitung von erratischem Dala-Sandstein außerhalb des Quellgebietes (schraffierte Fläche). Die gefüllten Kreise geben den prozentualen Anteil an der Gesamtsumme gezählter Geschiebe an jeder Lokalität an. Die gepunkteten Kreise kennzeichnen Schmelzwasserablagerungen. Die Vorkommen bei Gävle ( $N$ von Uppland) und Stockholm ( $S$ von Uppland), sowie die Streifen dazwischen, stammen aus lokalen Vorkommen (G. LUNDQVIST 1935, 1951). Die vom Autor eingefügte Doppellinie kennzeichnet die Grenze zwischen HESEMANNS Arealen II (NE der Linie) und III (SW der Linie), vgl. die Abb. 9. 


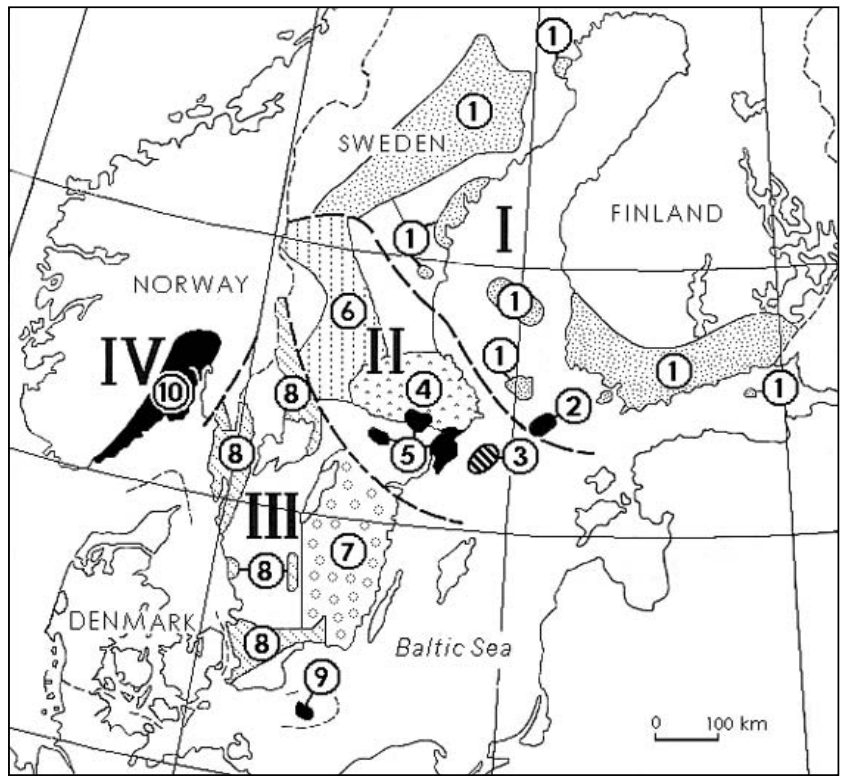

Fig. 9: Hesemann's subdivision of Norden (I-IV); Zandstra's revision (1983) is shown with Arabic numerals.

Abb. 9: Hesemanns Einteilung von Norden(I-IV); Zandstras Uberarbeitung (1983) ist mit arabischen Ziffern eingetragen.

of these seem to be dubious as indicators; (B) that limestone erratics are excluded; (C) that the outcrop areas of the used crystalline types are not equally distributed on a map of the Nordic countries; and (D) that the indicator type selection cannot be changed if counts from different localities have to be compared by means of the TGZ calculations.

(A) A number of sandstone types are found in LütTiG's indicator list (1958). However, in my opinion, only few sandstones can reveal their origin with sufficient certainty. It seems appropriate to discuss the most prominent examples:

Red sandstones derive mainly from the Jotnian formation, aged about 1200 my. They crop out in Dalarne and on the Baltic sea floor N, S, and W of the Åland islands. A fair number of hand-sized Dala sandstone specimens display circular light spots with distinct outlines, whereas such spots are seldom found in abundant red sandstone erratics on the Alland islands (VINX, pers. comm.) When from a large number of red sandstones no specimens have circular spots, there is good reason to believe that the till in question has a Baltic provenance. Many Baltic tills display red smears or strikes deriving from crushed sandstones. The mentioned traits are, however, not always reliable.

Oेved sandstone (Silurian, Scania) and Neksø sandstone (Subcambrian, Bornholm) are red. Öved sandstone can be used as indicator if it contains casts or moulds of 1-5 mmsized ostracod shells. Of the Neksø unit, only the bottom layers containing kaolinized feldspar grains can be recognized. All other specimens should be discarded, since it is impossible to distinguish them from Jotnian types in practice (SCHUdDEBEURS 1980-81).

Hardeberga sandstone (Cambrian) has visible, rounded sand grains embedded in a hard quartz cement; when struck, it splits across the grains; the fractures are rough and cut one another in odd angles. The colour is whitish, beige, greyish, or slightly greenish. The type should be recognizable, but it is found in SE, middle, and NW Scania, furthermore on Bornholm, and on the Baltic sea floor $\mathrm{N}$ of Åland as well. In German counts, Hardeberga sandstones are managed as indicators from Scania, but this is unfortunate, since many specimens can be of Baltic origin. Ice passing Bornholm on its way towards Schleswig-Holstein, Niedersachsen, the Netherlands, or Denmark will contain "Baltic" clast assemblages, whereas rocks from middle or NW Scania are only found in tills of "Swedish" provenance. Thus, Hardeberga sandstones cannot show the important distinction between Swedish and Baltic stages of a glaciation. Hardeberga sandstones are listed in several published counts where none of the easily recognizable Scanian volcanic rock types are recorded (basanite, basalt, melaphyre). This suggests that the sandstones in question derive from other areas than Scania.

Höor sandstone (Jurassic, Scania) should be more porous than the Cambrian and Precambrian types, but according to VINX (pers. comm.) this trait is not reliable.

(B): In contrast, Palaeozoic limestone types in most cases seem to be reliable as indicators in tills that are not depleted of $\mathrm{CaCO}_{3}$, because their distribution in the Baltic area is huge in comparison to minor distribution areas in Sweden and Norway.

Originally, the TGZ method was invented with reference to Niedersachsen. This landscape (between the rivers Elbe and Ems, NW Germany) lies outside the outer limit of Weichselian ice sheets. As an example, the Osterholzer Geest north of Bremen is dominated by a till from the Drenthe substage of the Saale glacial. The till cover is $2-4 \mathrm{~m}$ thick and is generally depleted of $\mathrm{CaCO}_{3}$, especially because it overlies thick meltwater sands, a situation that intensifies the percolation of $\mathrm{CO}_{2}$ through the till. However, in areas near the Elbe, and further to the NE in Schleswig-Holstein, Saalian tills occur which contain smears and floes of chalk. Here, the $\mathrm{CaCO}_{3}$-depletion only reaches the top 1-2 m, and Palaeozoic limestones are present. To be able to compare, LütTig decided to omit limestones from his counts.

An important objection against LüTTIG's exclusion of limestones is that a till will be interpreted as "of Swedish provenance" when Swedish stones dominate the collection of crystalline indicators, even if Palaeozoic limestones are present.

Fortunately, GoRSKA-ZABIELSKA has made some counts from Polish tills, in which both sandstones and limestones were recorded (BösE \& GóRSKA 1995, supplemented by GóRSKA-ZABIELSKA, pers. comm.). With her permission, I have drawn the two corresponding circle maps shown as fig. 10 .

In fig. 10, the left-hand map is based on LüTTIG's indicator type selection. BÖSE \& GóRSKA (1995) state that the Poznan-Leszno till (i. e., the till underlying the "Chodziez" till) contains a majority of clasts from eastern Sweden. It can be concluded that in the Chodziez till, the Åland stones and the Eastern Baltic sedimentary rocks must have been transported directly from the outcrops, whereas the Swedish clasts are most probably reworked. Thus, the TGZ in the left-hand map is misleading, since it is based mainly on reworked clasts. Baltic rocks are under-represented in LÜTTIG's indicator list (1958): Bornholm and Åland are the only Baltic crystalline-rock source areas from which stones are found in significant numbers in tills in NW Germany. Since no limestone types are included, a "dead sector" arises in 

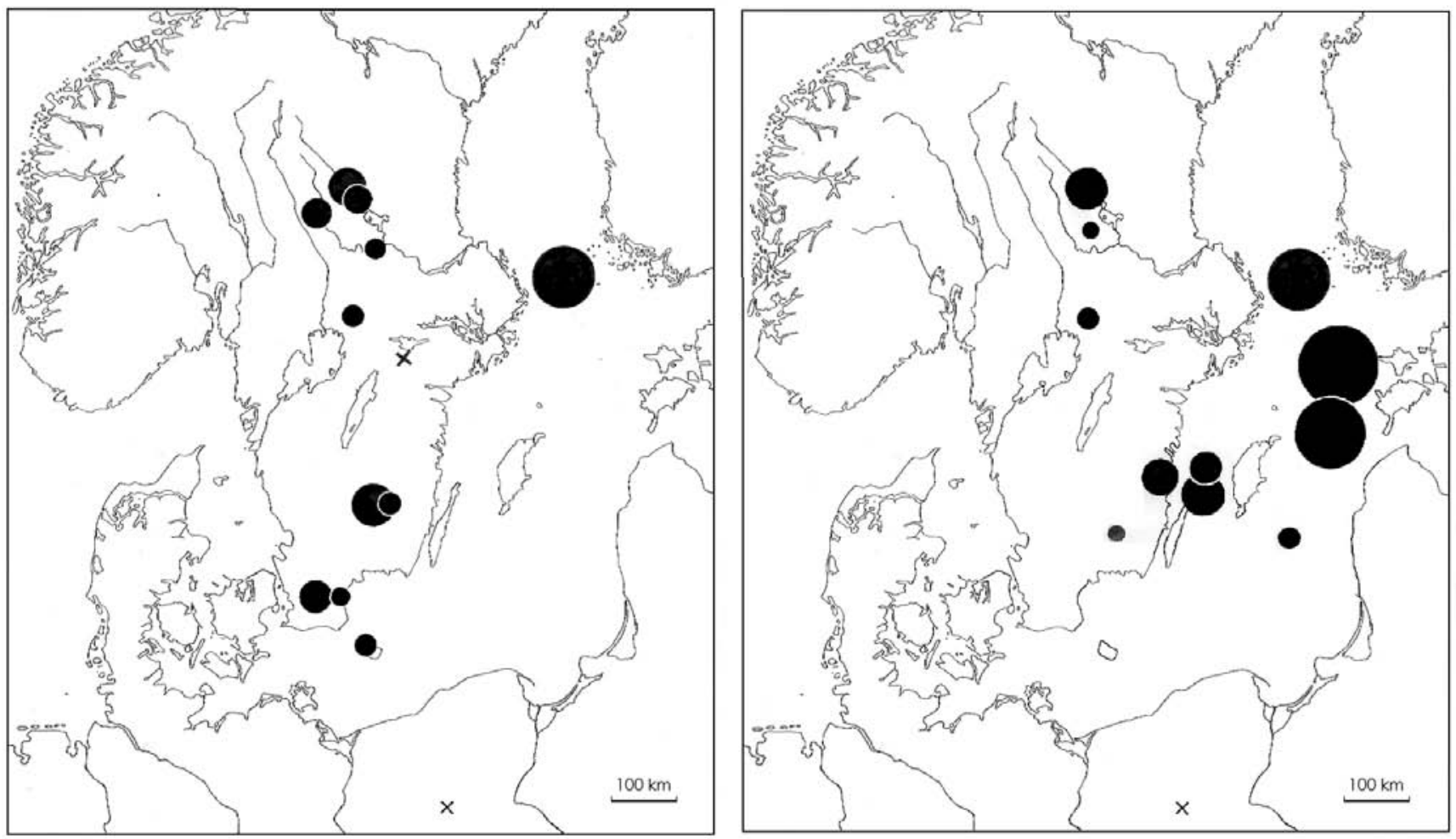

Fig. 10: Two different presentations of an indicator count from the Weichselian Chodziez till, Ujscie, Poland. The left-hand map shows a count based on LÜTTIG'S indicator list (1958), i. e. it includes crystallines and sandstones. It is taken from BÖsE \& GóRSKA (1995: p. 7). The cross in Sweden marks the TGZ, the cross in Poland marks the sampling site. The right-hand map is drawn from the original indicator lists (GóRSKA-ZABIELSKA, pers. comm.) It includes the crystallines and the selected sedimentary indicator types shown in the list p. 84.

Abb. 10: Zwei unterschiedliche Darstellungen von einer Geschiebezählung am weichselzeitlichen Chodziez till, Ujscie, Polen. Die linke Abbildung zeigt Geschiebezählung nach der von LüTTIG beschriebenen Indikatorliste (1958), die Kristallin und Sandsteine beinhaltet (nach BösE ひ GóRSKA 1995: 7). Das Kreuz in Schweden markiert das TGZ, das Kreuz in Polen den Probenpunkt. Die rechte Karte ist nach der Originalliste von GóRSKA-ZABIELSKA (pers. Mitteilung) ausgearbeitet worden. Sie beinhaltet Kristallin und paläozoische Sedimente, die unten in der Liste dargestellt sind.

the rest of the Baltic area. In fig. 10, left-hand map, some small circles appear in eastern Sweden, and Åland can be seen at the top, but the centre of the image is empty, where the most substantial information should normally appear. The case is of importance, because ice movements from Norden to Poland, the Baltic States, the eastern part of Germany, and most of Russia have definitely passed the Baltic sea.

Thus, with the TGZ method the ice transport path through the Baltic depression is not visible and can only be deduced from the till's content of sedimentary clasts as described in the explanatory text. Meyer (pers. comm.) has argued that circles representing Palaeozoic limestones (PK) types cannot be drawn, because the outcrop areas are not known precisely. However, verbal descriptions are even less precise than a circle placed according to our present knowledge would be. Conclusions such as "Large amounts of PK + many dolomites = East Baltic provenance" are derived from an "imaginary map" of the distribution of rock types on the sea floor. The sediments are thus actually used, but with the serious disadvantages that no percentages or numbers are given, and that the "imaginary map" cannot be checked.

Palaeozoic limestones cover an area of the Baltic sea floor that is larger than the combined source areas of all Swedish indicator rocks. PK clasts are 10-100 times more abundant in a fine gravel analysis than the number of indicators in a count. If anything, this means that the total number of Palaeozoic limestone clasts should be compared to the total sum of all crystallines. When the Swedish indicator rock types are depicted separately, it would not be reasonable to sum up all limestone samples and show them as one circle; if this is done, the Baltic depression will be greatly over-represented. To provide circles for the Baltic area, the requirements must be adjusted to the level used for other indicators, namely that the specimens belong to well-defined rock types with a limited source area. Uncharacteristic small pebbles will then be omitted - exactly as uncharacteristic granite samples normally are. In the right-hand map on fig. 10, as well as on fig. $5,6,7$, I have followed this principle by depicting selected sedimentary rock types (cf. SMED 2000). For convenience, a list of geographical coordinates for these types is repeated here:

\begin{tabular}{|l|l|l|}
\hline Types & Latitude & Longitude \\
\hline Devonian sediments & 56.7 & 19.7 \\
\hline Dolomite & 58.4 & 21.6 \\
\hline Gotland limestone & 57.6 & 18.4 \\
\hline Palaeoporella limestone & 57.6 & 17.3 \\
\hline Red Öland limestone & 56.7 & 16.6 \\
\hline Red-white Baltic limestone & 58.9 & 21.4 \\
\hline
\end{tabular}

The coordinates are mainly based on the National Atlas of Sweden, volume 6, Geology. This source was supplemented with information from Hucke \& VoIGt (1967), LÜTTIG (pers. comm.), VINX (pers. comm.) and GóRSKAZABIELSKA (pers. comm.) 
The chosen types are advantageous, because each of them occurs in limited source areas: red Öland and Palaeoporella limestones come from the western, Gotland limestones from the central, and dolomites, red-white limestones, and Devonian sediments from the eastern part of the Baltic depression. By including them it should be possible to distinguish between eastern, central, and western Baltic transport paths directly from the circle maps.

Apart from a reference to existing tills that are depleted of $\mathrm{CaCO}_{3}$, MeYER and LütTIG (pers. comm.) have raised some further objections to the limestone depiction: (1) The alleged "red Olland" type is found north as well as south of the Åland islands, but this does not upset the counts, since in practice the transport paths from both areas coincide: they run through the Baltic depression towards Denmark as well as towards the Netherlands, Poland or Germany. (2) VinX, Grube \& Grube (1997) discuss an example where red "Olland-like" limestones are found together with Kinne diabases in an Elsterian till in Holstein. The conclusion was that, in this case, the limestones derive from Västergötland (E of the lake Vänern, Sweden). However, the combination is unusual (I have never seen it in Denmark), and it should pose no problem to reveal it when it occurs. According to VINX, a further clue supported the conclusion: the till contained black shale fragments in an amount rarely seen in combination with clasts from Öland.

(C) The bulk of indicator types used by both Hesemann and LüTTIG derives from source areas lying in a belt from Dalarne to eastern Småland. From neighbouring areas, SW Sweden, Norway, and the Baltic sea bottom, few or no types are included; stones from Åland and the Oslo field are exceptions, but Åland rocks are normally a minority in German counts, and Oslo stones are almost never found. Thus, the distances between the TGZ positions are small; in most counts they lie in eastern Sweden. Even in counts from the Netherlands few TGZs are situated to the $\mathrm{W}$ of $15^{\circ}$ Eastern length, i. e. the longitude of Bornholm. It is well known that large parts of the Quaternary ice sheets have reached Germany passing western Sweden, Denmark, or the Baltic sea, but this is poorly reflected in LÜTTIG's diagrams.

ZANDSTRA (1983) saw that a distinction between clasts of SW Swedish and SE Swedish origin could be important. Therefore, a new subdivision was proposed where area 7 represents SE Sweden and area 8 SW Sweden (fig. 9). A comparison of fig. 5 with fig. 8 shows that this distinction is significant. However, ZANDSTRA's innovation is most probably of little consequence if LÜTTIG's indicator selection is still used.

(D) With the TGZ method, each count must be done using an identical indicator type selection, because the introducing of new types would disturb the grouping of points in the diagrams. As mentioned above, the conditions in Niedersachsen led LüTTIG to abandon the counting of limestones. This means that limestones must be excluded from all counts conducted after the TGZ method, even in Weichselian tills where it could improve the results to add them, cf. fig. 5, 6, 7, 10 .

Kinne diabase was almost the only western Swedish indicator type in use in 1958, the year when LüTTIG published his method. Thus western Sweden shared the fate of the Baltic sea floor: the TGZ calculations does not allow to include rock types from this area. The problem cannot be overcome if the TGZ method is applied.

The circle-map depiction method offers more flexibility. New types can be added to the circle-maps without seriously disturbing a comparison to older results, as long as the balance between the main source areas is kept. It could be seen as a continuous task to refine the method.

\subsection{Indicator counts and fine gravel analysis}

As mentioned, in the German count tradition only crystalline rocks were considered (KoRn 1927, HesemanN 1936, 1975, ZANDSTRA 1988, 1999); in LÜTTIG's lists (1958) sedimentary indicators only constitute a minority. Instead, a Baltic provenance ought to be revealed by fine gravel analyses. However, as shown by FAURBYE (1999) and by KJÆR et al. (2003), the results of these do not always coincide with the indicator counts. It seems appropriate to discuss this in some detail. In eastern Denmark, the Mid Jutland till (HouMARK-NIELSEN 1987) has Swedish provenance and is interpreted as deposited during the stage when the ice cover reached the Mid Jutland marginal line some 23-21 kyr bp. This till is found at Hjelm Nakke as well as in the "Kolonien Østersøen” cliff on Møn (Faurbye 1999). The counts in the Mid Jutland till are combined in fig. 5, left-hand map. Among the clasts in Faurbye's fine gravel count of this same till, Palaeozoic limestones (presumably from the Baltic depression) were dominant. Nevertheless, FAURBye interpreted the till provenance as Swedish, based on (a) indicator lists, (b) till fabric analysis, and (c) glacial tectonics, showing an ice movement from NE (cf. fig. 4). KJÆR et al. (2003) follow FAURBYE, pointing out that Palaeozoic limestones dominate the fine gravel composition even in tills of Swedish provenance in the entire SE Denmark, whereas only a modest percentage of the (normally larger) indicator clasts in such tills derive from the Baltic area. In the search for an explanation, it could be emphasized that pressuremelting occurs when the base of a temperate glacier slides over stones whose upper faces rise over the substratum. Such stones are pressed downwards and receive striae. It may be suggested that clasts $<2 \mathrm{~cm}$ are too small to cause a sufficient pressure-melting; they could be picked up, transported, and deposited as parts of the till matrix instead. As a consequence, the small clasts should be more susceptible to re-entrainment.

This difference in the handling of small and larger clasts could possibly be deduced from observations made by Humlum (1980) in Iceland: it was shown that many stones of medium size (roughly $6-50 \mathrm{~cm}$ ) are not deposited until the ice melts that is embedding them. They are then laid down as a pavement upon the surface of the already deposited till; if a readvance occurs, they are supplied with striae. (Thus stones and striae derive from different advances). In contrast, the glacier base transports and deposits pebbles under $2 \mathrm{~cm}$ size with the till matrix.

Two examples from Møn illustrate further problems with fine-gravel analysis:

(1) Indicator counts were made by me in the Klintholm till (HoumARK-Nielsen 1994) at five localities; fig. 5, 6, and 7 show representative examples. All five counts showed a path of ice transport from the Scandinavian mountains via 
Dalarne through south-eastern Sweden, running along the east coast of Småland, and via Blekinge towards Møn, cf. p. 78. HoumArK-NieLSEN et al. (2005) described the Klintholm till's provenance as "Baltic", led by the presence of many Oland specimens in fine-gravel analyses. The transport path seen on fig. 5, 6, and 7 reveals that this is not entirely true. It is especially striking that no Åland rocks, but many specimens from Dalarne and Småland, were observed. In my opinion, the designation "Baltic provenance" cannot be used in such a case; it must be replaced by "Swedish east coast provenance".

As mentioned, current German methods (LüTTIG 1958) do not incorporate limestones. If this restriction had been applied, Klintholm till's provenance should be interpreted as "Swedish", a conclusion that might be reached when looking at fig. 11. However, fig. 5, 6, 7 show that this designation is also imprecise. It can be concluded that when some limestone types are included in the indicator counts in combination with the crystallines, this can improve the precision obtained by fine-gravel analyses, as well as by the current German count methods.

(2) The Hvideklint cliff section was investigated by ABER (1979). He found imbricate chalk slabs stacked by ice thrust from the N/NE/E (ABER 1979: p. 87). Between the slabs and as a cover above them, three till units were found. The middle unit was referred to as the "upper dislocated till". The uppermost unit, called the "discordant till", blankets the land surface. ABER interpreted both these units as deposited by the "NE ice" (Mid Jutland advance), i. e. they should have a Swedish provenance. Indicators were counted by me in the two layers; the results are shown in fig. 6. Note that in the left-hand map no large number of limestones could be expected, since the count was made less than $1 \mathrm{~m}$ below the land surface. Even so, it is clearly shown that the "discordant till" has a Baltic, not a Swedish provenance; it must be assigned to the Young Baltic ice advances. Every detail in the sample from the "upper dislocated till" matches the Klintholm till counts: (a) clasts come from the eastern Småland coastal area as well as from the neighbouring sea floor; (b) a sharp western boundary exists, no stones from W Sweden are found except one; (c) very few Åland rocks, but many Småland granites were found; (d) white-spotted flints and Kalmarsund sandstones were present. The differences from the Mid Jutland till (fig. 5) are obvious: ABER's "upper dislocated till" is not a Mid Jutland till, but is identical with the Klintholm till.

ABER's till interpretations were based on fine gravel analyses. Fig. 13 is reproduced from ABER 1979: p. 89. The diagram shows only small differences between the "upper dislocated" and the "discordant" tills. As far as I can see, the drawback is that the subdivisions in the left diagram are too coarse: no distinction has been made between red sandstones and other sandstones, and all crystalline clasts are combined, regardless of their origin. It can be concluded that the indicator counts are far more informative than the depicted fine gravel analyses.

\subsection{Clast size limits}

In a particular till, large as well as small stones have been transported by the same ice advance. It seems unfortunate

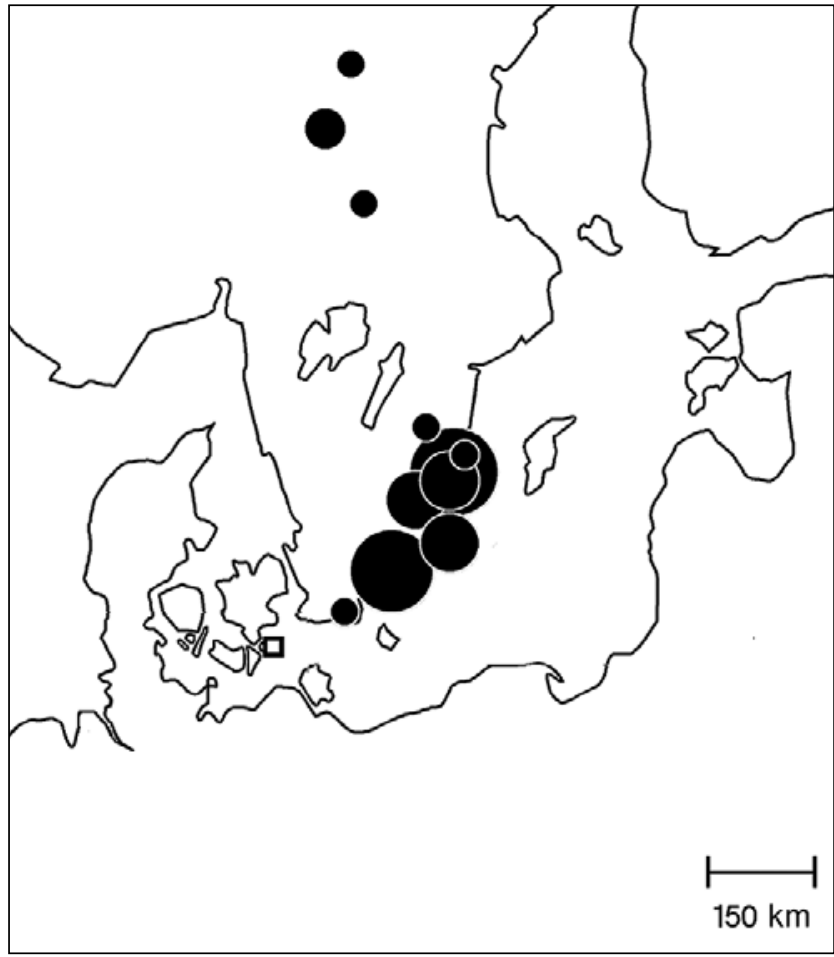

Fig. 11: The same indicator count of the Klintholm till from Hjelm Nakke as in fig. 7. The map is modified as if a current German indicator rock selection had been applied, i. e. Oland, Palaeoporella, Beyrichia and Gotland limestones are removed.

Abb. 11: Dieselbe Geschiebezählung vom Klintholm Till aus Hjelm Nakke wie in der Abb. 7. Die Karte wurde unter Verwendung der aktuellen deutschen Leitgeschiebezählungs-Methoden angepasst, d.h. dass Öland-, Palaeoporella-, Beyrichia- und Gotland Kalksteine nicht berücksichtigt wurden.

to use a maximum clast size of $6 \mathrm{~cm}$, because some Nordic areas deliver mostly small clasts, whereas samples from other areas tend to be larger than $6 \mathrm{~cm}$. If a count comprises stones smaller than $6 \mathrm{~cm}$ only, Dala porphyries will tend to dominate among the indicators. Porphyry specimens from other areas are often larger; the same is the case with Kinne diabases and granites. Dalarne will be over-represented in the $<6 \mathrm{~cm}$ fraction; a granite region as Värmland will be under-represented. On the whole, western Sweden (including Scania) will be under-represented. Large areas could remain invisible in the counts, although the ice may have moved directly over them. Already Hesemann (1935) stated that "it is not advisable to throw away information, even if it is given by a granite". Thus, no maximum clast size shall be recommended. The balanced solution seems to be to count both small and large stones.

In practice, a minimum size is set by the possibility of recognition. This can cause a certain imbalance, e. g. because $1 \mathrm{~cm}$-sized Åland granite samples can be recognized, whereas other granite samples of similar size cannot. However, this seems to be of minor importance. As an example, Åland rocks are common in the Young Baltic and Ristingeklint tills, but rare in the Mid-Jutland and Klintholm tills; this contrast is not masked in the counts.

If the entire number of clasts in a studied profile area is required (i. e. including flint, gneiss, shale, quartz grains, etc.), a lower clast size limit must be applied; if not, the task would be impossible (should microscopic ones be included?) However, in spite of its desirability (cf. p. 76), no known publications have given such a total number. 


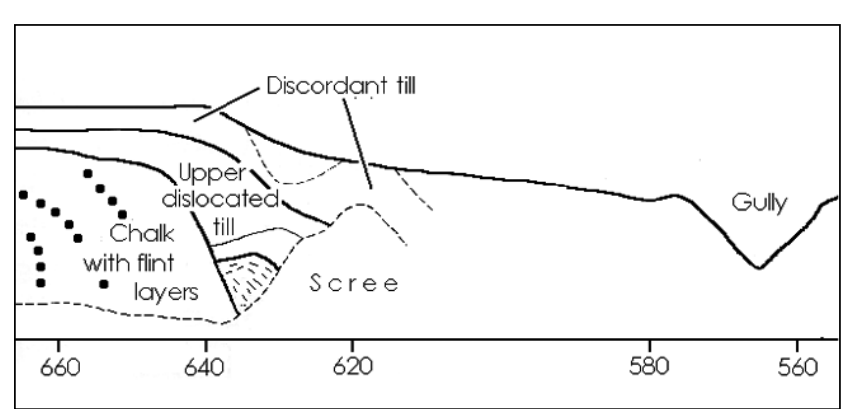

Fig. 12: The northern end of the Hvideklint cliff. The distance in $m$ from the end of the road Ørebækvej is given. Both samples were taken above the $640 \mathrm{~m}$ mark.

Abb. 12: Das nördliche Ende des Hvideklint-Kliffs. Der Abstand zum Ende des Ørebækvej ist angegeben. Beide Proben wurden oberhalb der $640 \mathrm{~m}$ Marke entnommen.

\subsection{Reworked clasts}

As a main rule, a more or less broad band can be observed on the circle maps, connecting the Scandinavian mountains with the sampling site. In most cases the band narrows when the locality is approached. It can be seen in fig. 6, right-hand map, that only one specimen was recorded from western Sweden (a Scanian granulite). The conclusion must be that this clast has been reworked.

In fig. 5 (right) the transport path has a rather sharp western border. A similar border is displayed in the left-hand map, but it is here situated further to the W. As a contrast, some central Baltic clasts were found in both counts. In such cases it is helpful to consider which clast spectra are found in the underlying tills. In the mentioned case, these were found to contain many Baltic clasts. This means that some Baltic material has been reworked and incorporated in the younger till.

These two examples show that circle-maps sometimes reveal the presence of reworked clasts. LüTTIG's method (1958) is not suitable for this purpose, since the total clast composition in a count is depicted as one point in a diagram only, and the details are concealed. Reworked clasts should be excluded from the TGZ calculations by rights, but such a precaution is not possible.

The identification of reworked clasts is only possible if they constitute a modest percentage of the sample. However, examples are known where slabs of older till are worked up, so that their clast content dominates.

\section{Conclusions}

The results of indicator counts of three Weichselian tills on the island Møn, Denmark, are discussed (localities, see fig. 1,2). The three tills differ in character. Neither the previously used count depiction methods nor the alternatively applied fine gravel analyses could reveal the true provenance of the tills. This was only possible by applying the circle map method (fig. 5, 6, 7).

The oldest mentioned approach was that of MiLTHERs $(1909,1942)$. The method is no longer used by geologists today. MiLThers's method results in a strong under-representation of Swedish rock types.

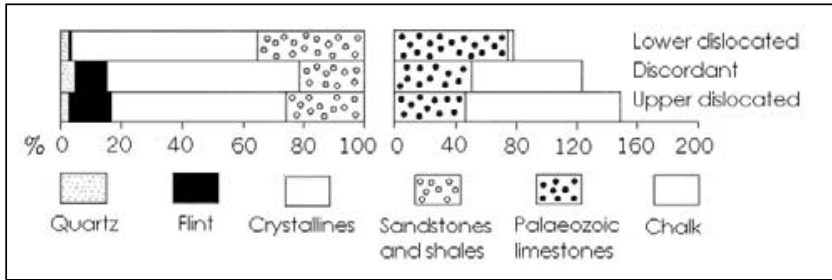

Fig. 13: Fine gravel analyses of the tills at Hvideklint (clasts of 3-5 mm size). The left diagram shows the non-carbonate fraction, calculated as \%. The right diagram shows carbonates calculated as a percentage of the noncarbonate fraction. (From ABER 1979: 89).

Abb. 13: Feinkieszählungen des Tills vom Hvideklint (3-5 mm Größenklassen). Das linke Diagramm zeigt die nichtkarbonatische Fraktion (in \%), das rechte Diagramm die karbonatische Fraktion als prozentuzalen Anteil von der nicht-karbonatischen Fraktion (nach ABER 1979: 89).

HesemANN's rock type selection (1936, 1975) was more comprehensive and is still in use with slight modifications. Its weak points are that the four source areas are too large, and that their boundaries do not reflect the ice movement patterns. If HesEmanN's subdivision (fig. 9) had been used, no difference could be detected between the transport paths of the Mid Jutland and Klintholm tills. ZANDSTRA (1983) has improved this situation by subdividing HesemanN's four source areas.

In LÜTTIG's method (1958) the total result of a count was shown as one point in a diagram only (the TGZ). Individual rock types were not depicted and. as a main rule, indicator lists were not published. Thus, it was concealed that western Sweden and the Baltic sea floor are under-represented in Lüttig's (1958) list of indicator types. Therefore, it is doubtful whether the distinct difference between the Mid Jutland and Klintholm tills could have been detected with the LüTTIG method either. The left-hand map in fig. 10 shows that by disregarding all types of Baltic limestones the alleged source area of the till in question was shifted far to the west. Furthermore, most of the included sandstones are not well-defined.

FAURBYe (1999) and KJÆR et al. (2003) have shown that the results of fine gravel analysis do not always coincide with the results achieved by indicator counting. These authors found that indicator counts were preferable because their results were in better agreement with the results of other investigation methods. The cause of the discrepancy is still uncertain. In the opinion of the present author, it seems probable that larger stones are less susceptible to reworking than clasts $<2 \mathrm{~cm}$ size. Consequently, the fine gravel would contain more reworked material than the larger fractions.

The present author cautions against using a size limit such as $2-6 \mathrm{~cm}$ for the counts, because certain Nordic source areas deliver mostly large clasts (e.g. granites), whereas other regions do not. As an example, Värmland will be under-represented and Dalarne over-represented in the counts, if stones larger than $6 \mathrm{~cm}$ size are omitted.

It is emphasized that indicator counts depicted as circlemaps come closest to revealing the true paths of former ice movements. In many cases. the circle-maps allow a distinction between clasts transported directly from the source areas and reworked clasts. 
Some results are of local interest for the glacial geology of the island Møn: it is shown that Houmark-NiELSEN's (2005) interpretation of Klintholm till as "of Baltic provenance" cannot be supported, and that ABER's (1979) identification of the till units in Hvideklint was faulty.

\section{Acknowledgements}

Michael Houmark-Nielsen, Copenhagen, encouraged this work. Maiken Faurbye (Copenhagen) and Maria GórskaZabielska (Poznan) allowed me to quote their work. Roland Vinx and Jürgen Ehlers, both Hamburg, Johannes Krüger and Kurt-Henrik Kjær, both Copenhagen, Hans-Jürgen Stephan, Kiel, and K.-D. Meyer, Hannover, gave advice and information. The English language was improved by Jürgen Ehlers and by Alicia Boyens-Thiele, Copenhagen. Finn Uno Kofoed, Haslev, and Margit Johansen, Copenhagen, assisted me in the field. I am very grateful to all these people.

\section{References}

ABER, J. S. (1979): Kineto-stratigraphy at Hvideklint, Møn, Denmark, and its regional significance. - Bulletin of the Geological Society of Denmark, 28/1979: 81-93.

BÖSE, M. \& GóRSKA, M. (1995): Lithostratigraphical studies in the outcrop at Ujscie, Torun Eberswalde Pradolina, western Poland. - Eiszeitalter und Gegenwart, 45: 1-14.

FAURBYE, M. (1999): En kvartærstratigrafisk og strukturgeologisk undersøgelse af klintprofilet Feriehjemmet på det sydlige Møn, Danmark. Specialeafhandling, Geologisk Institut, Københavns Universitet, unpublished: $111 \mathrm{p}$.

Hesemann, J. (1931): Quantitative Geschiebebestimmungen im norddeutschen Diluvium. - Jahrbuch der Preussischen Geologischen Landesanstalt, Neue Folge, 51: 714-751.

Hesemann, J. (1935): Ergebnisse und Aussichten einiger Methoden zur Feststellung der Verteilung kristalliner Leitgeschiebe. - Jahrbuch der Preussischen Geologischen Landesanstalt 1934, 55: 1-27.

Hesemann, J. (1936): Zur Petrographie einiger nordischer kristalliner Leitgeschiebe. Abhandlungen der Preussischen Geologischen Landesanstalt, Neue Folge, 173: $167 \mathrm{p}$.

Hesemann, J. (1975): Kristalline Geschiebe der nordischen Vereisungen. Geologisches Landesamt Nordrhein-Westfalen, 267 p.

Hintze, V. (1937): Møns Klints Geologi. - 410 p; København (C. A. Reitzels Forlag).

HoumARK-NieLsen, M. (1987): Pleistocene stratigraphy and glacial history of the central part of Denmark. - Bulletin of the Geological Society of Denmark 36/1-2: $189 \mathrm{p}$.

HoumARK-Nielsen, M. (1994): Late Pleistocene stratigraphy, glaciation chronology, and Middle Weichselian environmental history from Klintholm, Møn, Denmark. - Bulletin of the Geological Society of Denmark, 41: 181-202.

HoumarK-Nielsen, M. ひ KJÆR, K. H. (2003): Southwest Scandinavia, 40-15 kyr BP: palaeogeography and environmental change. - Journal of Quaternary Science 18, 769-786.

Houmark-Nielsen, M., KRÜGer, J., ひ KJÆR, K. H. (2005): De seneste 150.000 år i Danmark. - Geoviden 2005. 2: 1-19.

Hucke, K. ひ VoIgT, E. (1967): Einführung in die Geschiebeforschung, Sedimentärgeschiebe. - 132 p; Oldenzaal (Verlag Nederlandse geologische Vereniging).
Humlum, O. (1980): Observations on debris in the basal transport zone of Myrdalsjökull, Iceland. - Annals of Glaciology, 2: 71-77.

KoRN, J. (1927): Die wichtigsten Leitgeschiebe der nordischen kristallinen Gesteine im norddeutschen Flachlande. - Preussisch geologische Landesanstalt, $64 \mathrm{p}$.

KJÆr, K. H., Houmark-Nielsen, M. $\mho$ Richardt, N. (2003): Ice-flow patterns and dispersal of erratics at the southwestern margin of the last Scandinavian ice sheet: signature of palaeo-ice streams. - Boreas,. 32: $130-148$.

KrAAG, B. (1978). Falsters og Bogøs geomorfologi. - Unpublished report, Geografisk Institut: 85 p. (Københavns universitet).

KRÜGER, J. (1969): Landskabsformer i sydlige Sjælland. - Geografisk Tidsskrift, 68: 107-212.

KRÜGER, J. \& KJÆR, K. H. (1999): A data chart for field description and genetic interpretation of glacial diamicts and associated sediments, with examples from Greenland, Iceland and Denmark. - Boreas , 28: 386-402.

LuNDQVIST, G. (1935): Blockundersökningar. Historik och metodik. - Sveriges geologiska Undersökning Serie C, 390: 45 p.

LuNDQvisT, G. (1951): Blockmaterialet i morän och isälvsavlagringar. Sveriges geologiska Undersökning Serie Ca, 21: 213 p.

LÜtTIG, G. (1958): Methodische Fragen der Geschiebeforschung. - Geologisches Jahrbuch Band, 75: 361-417.

Milthers, K. (1942): Ledeblokke og landskabsformer i Danmark. - 137 p + additional Vol 43 p.; København (C. A. Reitzels Forlag).

Milthers, V. (1909). Scandinavian indicator boulders in the Quaternary deposits. - Danmarks Geologiske Undersøgelse, II. Række Nr. 23: 153 p.

National Atlas of Sweden (1994): Geology - Volume 6, Geological Survey of Sweden: $208 \mathrm{p}$.

Pedersen, S. A. S. \& Petersen, K. S. (1997): Djurslands geologi. - Danmarks og Grønlands Geologiske Undersøgelse (GEUS): 96 p.

Schuddebeurs, A. P. (1980-1981): Die Geschiebe im Pleistozän der Niederlande. - Der Geschiebesammler 13 (3-4), 14 (2-3) und 15 (1-2).

SJøRRING, S. (1983): Ristinge klint. - In: Ehlers, J. (ed.): Glacial Deposits in Northwest Europe: 219-226; Rotterdam (Balkema).

SMED, P. (1993): Indicator studies: a critical review and a new data presentation method. - Bulletin of the Geological Society of Denmark, 40: 332-344.

SMED, P. (1995): Sten i det danske landskab, 3. ed.: - 181 p.; Brenderup (Geografforlaget).

SMED, P. (2000): Über den Hesemann-Milthers-Streit und die von Hesemann verwendete Abbildungsmethode für Geschiebezählungen. - Geschiebekunde aktuell, 16 (4): 127-130.

Smed, P. (2002): Steine aus dem Norden, 2. verbesserte Auflage. - 194 p.; Berlin/Stuttgart (Borntraeger).

STOCKMARR, T. (1996): En kvartærgeologisk model over det sydvestlige Møn. - Specialeafhandling, Geologisk Institut, Københavns universitet. Unpublished: $164 \mathrm{p}$

VINX, R. (1996): Granatcoronit (mafischer Granulit), ein neues Leitgeschiebe SW-schwedischer Herkunft. - Archiv für Geschiebekunde Band 2, p. $1-20$.

VINX, R. (1998): Neue kristalline SW-schwedische Leitgeschiebe. - Archiv für Geschiebekunde, 2: p. 361-378.

VinX, R., Grube, A. \& Grube, F. (1997): Vergleichende Lithologie, Geschiebeführung und Geochemie eines Prä-Elster-I-Tills von Lieth bei Elmshorn. - Leipziger Geowissenschaften, 5: 83-103.

Wennberg, G. (1949): Differentialrörelser i inlandsisen. - Meddelanden från Lunds Mineralogisk-Geologiska Institution, 114: 200 p.

ZANDSTRA, J. G. (1983): A new subdivision of crystalline Fennoscandian erratic pebble assemblages in the central Netherlands. - Geologie en Mijnbouw, 62: 455-469.

ZANDSTRA, J. G. (1988): Noordelijke kristallijne Gidsgesteenten. - 469 p; Leiden (E. J. Brill).

ZandstrA, J. G. (1999): Platenatlas van noordelijke kristallijne Gidsgesteenten. - 412 p.; Leiden (Backhuys Publishers). 